Article

\title{
Individual and Combined Effects of Postharvest Heat Disin- festation Treatments Associated with a Modified Atmosphere Packaging (MAP) on the Quality of Algerian Dates Fruits (Phoenix dactylifera L.).
}

\author{
Mohamed Marouf Aribi ${ }^{1}$, Mustapha Khali ${ }^{2}$ and Lynda Boutekrabt ${ }^{3, *}$
}

1 Department of Biotechnology, Laboratory of Biotechnology and Plant Productions, Faculty of Nature and Life Sciences, University of Blida 1, B.P 270 Road of Soumâa-Blida, Algeria; mar-bio-tp@live.fr

2 The Technical Center for Agri-Food Industry (CTIAA), Ibn Khaldoun Street Boumerdès B.P 71A, Algeria; khalimustapha@yahoo.fr

3 The Thematic Research Agency in Biotechnology and Agri-food Sciences (ATRBSA); DG-Pr-BOUTEKRABTLynda@atrbsa.dz

* Correspondence: mar-bio-tp@live.fr

\begin{abstract}
The aim of the study was to assess the chemical and biochemical composition of heat-treated dates palm fruits (Phoenix dactylifera L.) cultivated in Algeria and stored under Modified Atmosphere Packaging (MAP). In this research, fresh dates palm fruits at harvest (Phoenix dactylifera L.) have been subjected at heat treatment at $55 \pm 2{ }^{\circ} \mathrm{C}$ for $20 \mathrm{~min}$ in a ventilated oven. The samples were packed in specific Polyethylene Terephthalate packaging (PET) bags with a thickness of $2.5 \mu \mathrm{m}$ under MAP condition. The effect of this heat treatment on date fruits quality was investigated during 5 months of storage at room temperature storage $\left(22 \pm 1^{\circ} \mathrm{C}\right.$ of temperature with 75 to $80 \%$ of relative humidity (RH), and $10 \pm 1^{\circ} \mathrm{C}$ with 85 to $90 \%$ of $\left.\mathrm{RH}\right)$. Chemical and biochemical composition of the samples were studied. Results indicated that during storage the Brix degree, protein, and vitamin $\mathrm{C}$ content changed significantly $(\mathrm{p}<0.05)$. The major change was observed for lipid values varied from about 0.02 to $0.06 \%$ at $10^{\circ} \mathrm{C}$, and 0.04 to $0.07 \%$ at $22^{\circ} \mathrm{C}$ for samples not heat-treated unpacked after 5 months of storage, these results represent a highly significant difference $(\mathrm{p}<0.01)$. Harvesting at Tamr stage followed by treating the fruits with heat disinfestation packed in MAP, and storing at $10 \pm 1^{\circ} \mathrm{C}$ showed to be a promising method for maintaining dates fruits storage quality.
\end{abstract}

Keywords: Phoenix dactylifera L.; postharvest; modified atmosphere packaging (MAP)

\section{Introduction}

The cultivation of the dates has increased significantly in recent years [1]. Over the past 20 years, production has almost doubled (in 1996, about 5 million tons of dates were collected while in 2016 - about 8.5 million tons) [2]. Due to the increased production and exports, dates are now available all over the world and can be an inseparable part of the daily diet [3,4]. Dates are considered a high-energy food (300 calories/100 g) rich in: sugars providing quick energy intake [5], minerals [6], vitamins, phenols, flavonoids, anthocyanins and carotenoids with functional properties $[7,8]$. The soluble fiber helps against constipation [9]. The antioxidant properties of date fruits cultivars and varietes depending on the amount of phenolics, vitamins $C$ and $E$, carotenoids, and flavonoids 
present [10]. Dates are good source of energy as they consist of $70 \%$ carbohydrates, most of which are in the form of sugars; and dietary fiber, as $100 \mathrm{~g}$ of dates supplies $32 \%$ of the advisable daily allowance of dietary fiber [11]. Losses during harvesting, postharvest handling and marketing are high due to the incidence of physical and physiological disorders, pathological diseases and to insect infestation. Thus, the standard (CEE-ONU-DDP-08) [12], concerning the marketing and the commercial quality control of dates published by the UN in 2010, contains provisions concerning: the qualities that dates must have at the export control stage, after conditioning and packaging, sizing, tolerances, presentation and marking. Modified Atmosphere Packaging (MAP) is one of the convenient packaging methods that could be useful in reducing the wastes and extending the crops' shelf life. Exposing dates to temperatures of 65 to $80^{\circ} \mathrm{C}$ for 30 min to 4 $\mathrm{h}$ at high humidity controls insects [13]. Heated air at 50 to $55^{\circ} \mathrm{C}$ for 2 to $4 \mathrm{~h}$ (from the time the fruit temperature reaches $50^{\circ} \mathrm{C}$ or higher) is effective for insect disinfestation [14].

According to Khali, 2008 [15], on different thermal scales tested, the heat treatmentat $55^{\circ} \mathrm{C} / 20 \mathrm{~min}$, showed a significant reduction in the infestation of dates (destruction of eggs and larvae of Ectomyelois ceratoniae Zellers), in more of a more positive influence on the main quality criteria of the date and a better preservation of organoleptic and sensory characteristics. The purpose of packaging is to preserve food against spoilage (chemical, biological, physical and microbiological) and also to increase shelf life; thus, transportation is better and easier; in addition to packaging's ability to protect the product, the relative information about the product could also be transferred to the consumer, including storage conditions, usage instruction and nutritional value of the product [16].

The proposed alternative is a physical treatment, dry heat treatment, at $55^{\circ} \mathrm{C}$ during $20 \mathrm{~min}$ as disinfestation treatment, associated to modified atmospheres packaging in Polyethylene Terephthalate packaging (PET) film, and to follow their simple or combined actions on the chemical and biochemical composition of the date Deglet Nour during five months of storage in cold $\left(10^{\circ} \mathrm{C}\right)$ and at room temperature.

\section{Materials and Methods}

\subsection{Plant material}

The Deglet Nour variety dates, coming from the Tolga palm grove (Biskra-Algeria), were harvested on different regimes at the end of October (at Tamr stage), then transported and kept in cold rooms at $4 \pm 1^{\circ} \mathrm{C}$. The dates were sorted and separated from their branches and the infested or bruised dates were eliminated.

\subsection{Heat treatment}

The heat treatment was carried out for $20 \mathrm{~min}$ in a ventilated oven set at $55 \pm 2{ }^{\circ} \mathrm{C}$ using the Memmert Vacuum Ovens VO101 (Federal Republic of Germany). A not heat-treated control batch was constituted. Dates (Heat-treated or not) were divided into homogeneous batches in plastic trays. The proposed alternative is a physical treatment at $55 \pm 2^{\circ} \mathrm{C}$ for $20 \mathrm{~min}$ as a disinsectisation treatment, associated with a Modified Atmosphere 
Packaging and to follow their simple or combined actions on the chemical and biochemical properties of the date (Phoenix dactylifera L.) over a period of five months of cold storage $10 \pm 1^{\circ} \mathrm{C}$ and at room temperature $22 \pm 1^{\circ} \mathrm{C}$.

\subsection{Constitution of experimental batches and storage}

The dates are packaged in batches of $350 \pm 5 \mathrm{~g}$. The date samples were divided into two groups of batches with six samples each, corresponding to the storage period $(0,1,2$, 3,4 and 5 months) before to be tested for the first at room temperature $22 \pm 1^{\circ} \mathrm{C}$ with a relative humidity of 75 to $80 \%$ and the second at low temperature of $10 \pm 1^{\circ} \mathrm{C}$ with a relative humidity of 85 to $90 \%$ of $\mathrm{RH}$. After mixing the samples, they were randomly packed in 50 packages. The samples were packed in specific PET packaging (Polyethylene terephthalate) bags with a thickness of $2.5 \mu \mathrm{m}$ under modified atmosphere. Each package was filled with dates under the stated conditions and kept at two temperatures of $10 \pm 1^{\circ} \mathrm{C}$ and $22 \pm 1^{\circ} \mathrm{C}$ inside the refrigerated incubator. The samples stored in usual package were considered as control group. After 1, 2, 3, 4 and 5 months of storage, forty-two samples were subjected to nutritional proprieties tests (Table 1).

Table 1. Experimental batches.

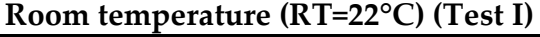

C1: (Control) not heat-treated - unpacked, preserved by freezing Lot 1: Not heat-treated - Unpacked: NTUP

Lot 2: Not heat-treated - Packed: NTP

Lot 3: Heat-treated - Packed: TP

Lot 4: Heat-treated - Unpacked: TUP

\section{Low temperature $\left(\mathrm{LT}=10^{\circ} \mathrm{C}\right)$ (Test II)}

C2: (Control) not heat-treated - unpacked, preserved by freezing Lot 1: Not heat-treated - Unpacked: NTUP

Lot 2: Not heat-treated - Packed: NTP

Lot 3: Heat-treated - Packed: TP

Lot 4: Heat-treated - Unpacked: TUP

\subsection{Chemical and biochemical analysis}

Moisture content and $\mathrm{pH}$ were quantified according to AOAC methods in triplicate [17]. Titratable acidity was evaluated in fruit juice by titrating with $0.1 \mathrm{~N}$ Sodium hydroxide $(\mathrm{NaOH})$ in the presence of phenolphthalein as an indicator and the results were expressed as a percentage of malic acid according to AL-Qurashi and Awad, 2011 [18]. Level of total soluble solids (TSS) was measured in supernatant as Brix percentage in fruit juice using a refractometer, a drop of date syrup was put on the plate of the refractometer. The Brix degree has been read directly on the scale at the intersection of the border between the light fringe and the dark fringe [19]. Total nitrogen was determined by the Kjeldahl technique [20], and protein was expressed as the general factor 6.25 [21]. Lipid was determined from dried dates by the Folch method [22]. The dosage of ash is based on the destruction of all organic matter under the effect of high temperature $\left(500 \pm 25^{\circ} \mathrm{C}\right)$. Place a test sample of date syrup in a muffle oven for 3 to $5 \mathrm{~h}$ at $500^{\circ} \mathrm{C}$. At the exit of the oven until the weight becomes constant (white or greyish white), place the samples in a desiccator for cooling. Weigh the cooled capsules [19]. Vitamin C values of samples were determined according to the Association of Official Analytical Chemists [23]. Total sugar has been identified by Dubois method and Bertrand method for reducing sugar; the sucrose content was obtained by the following formula: \% Sucrose \% Total sugar - \% Total 
reducing sugar [24]. Total sugars were determined by high-performance liquid chromatography [20]. Samples were spiked with various combinations of standard sugars (1-5 ppm) to monitor recovery, and the sugar concentration was calculated from peak area measurements [25]. The infestation rate is determined by the following formula: Number of infested dates / Number of dates observed $\times 100$ [26].

\subsection{Statistical analysis}

Results were expressed as mean \pm standard deviation; variability between samples of dates was determined by the ANOVA test, using STATISTICA software (STATISTICA V6.1). Significance was accepted at 0.05 level of probability $(\mathrm{p}<0.05)$. The experimental data were subjected to analysis of variance followed by a multiple range Duncan's test.

\section{Results}

\subsection{Variation of chemical composition of date fruit}

The Deglet Nour date samples stored at room temperature and at $10^{\circ} \mathrm{C}$ had a $\mathrm{pH}$ between 5.30 to 5.60. During storage, the results showed a clear and significant increasing trend, both at room temperature to reach respective values of 6.32 and 5.84 in the 2nd month and 5th month of storage. Under the action of heat treatment, $\mathrm{pH}$ was increased significantly $(p>0.05)$. The not heat-treated batches showed a non-significant increase in $\mathrm{pH}$ from the $1 \mathrm{st}(\mathrm{p}>0.05)$ to the 4 th month at room temperature, confirming to the trend observed in the not heat-treated control batches. Likewise, at $10^{\circ} \mathrm{C}$, the heat-treated batches showed a non-significant increase with average $\mathrm{pH}$ higher than their heat-treated counterparts and stored at room temperature or not heat-treated. The packaging of the dates also caused a not significant decrease in the $\mathrm{pH}$ of the samples of TP and NTP dates stored at $10^{\circ} \mathrm{C}$ in the 5 th month. On the other hand, the packaging of the dates also caused a non-significant increase in the $\mathrm{pH}$ of the samples of TP and NTP dates stored at room temperature for the 4 th month and 2 nd month.

The heat treatment-packaging combination showed an equally non-significant decrease $(p>0.05)$ for the heat-treated-packed batches stored either at room temperature or at $10^{\circ} \mathrm{C}$. The general evolution of acidity shows a general increasing trend. On the other hand, the unpacked, control batches stored at room temperature show a decrease in titratable acidity with average values ranging from 5.80 at 0 month to $5.15 \mathrm{mEq} / 100 \mathrm{~g}$ in the 5th month. This same trend was recorded in batches of dates stored at low temperature $\left(10^{\circ} \mathrm{C}\right)$ until the 5 th month $(6.43 \mathrm{mEq} / 100 \mathrm{~g})$; beyond, a decrease is recorded (4.59 $\mathrm{mEq} / 100 \mathrm{~g})$. The acidity values are significantly affected by the duration of storage. The NTUP and TUP batches show a significant decrease $(\mathrm{p}<0.05)$ in the average acidity up to the 5th month of storage but which remains high for the other months of storage, in particular in the 4 th month at room temperature of respective values of $(6.83 \mathrm{mEq} / 100 \mathrm{~g}$ and $6.85 \mathrm{mEq} / 100 \mathrm{~g}$ ). The comparison of the average acidity values shows an average acidity of $6.32 \mathrm{mEq} / 100 \mathrm{~g}$ for heat-treated batches stored at room temperature against a slightly lower average acidity $(5.82 \mathrm{mEq} / 100 \mathrm{~g})$ for their not heat-treated counterparts. While it is significantly lower at $10^{\circ} \mathrm{C}(5.14 \mathrm{mEq} / 100 \mathrm{~g})$. 


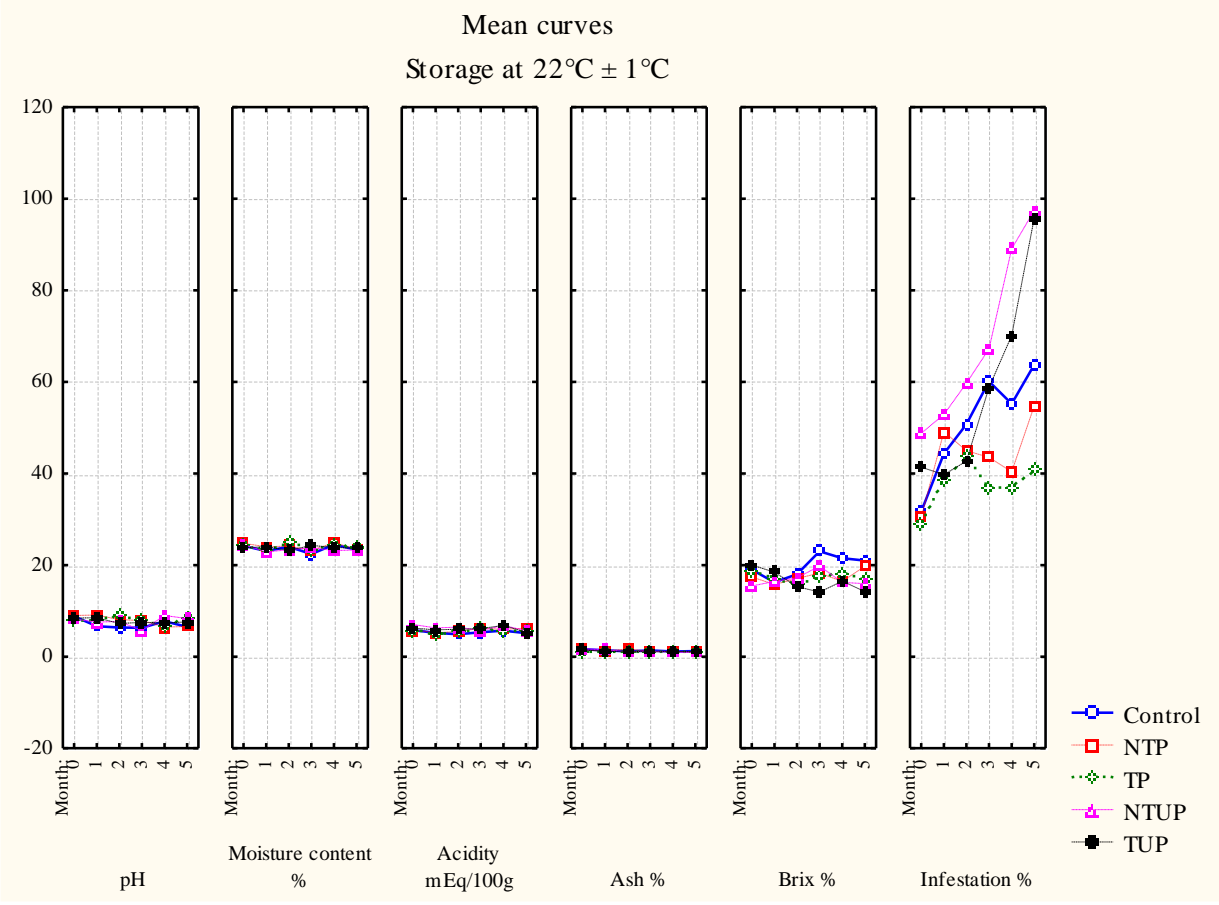

Mean curves
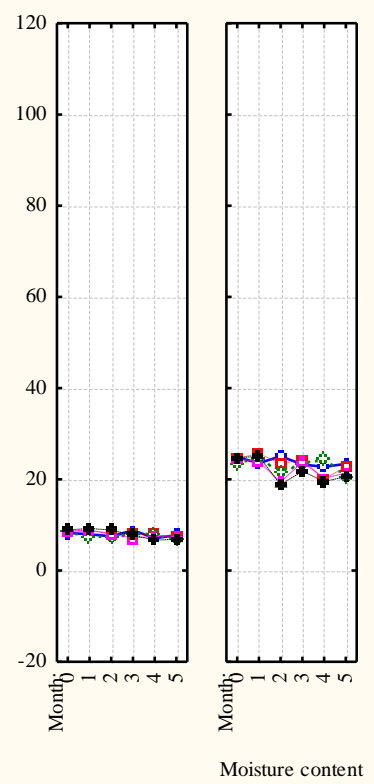

Storage at $10^{\circ} \mathrm{C} \pm 1{ }^{\circ} \mathrm{C}$
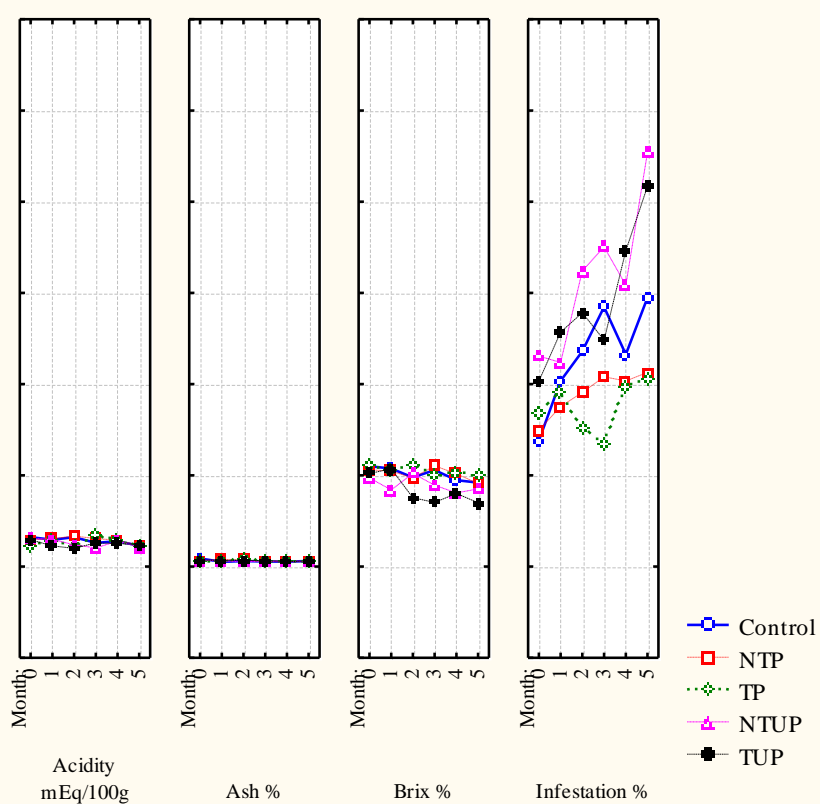

Figure 1. Means values of chemical composition of the samples of dates, stored at $22^{\circ} \mathrm{C}$ and $10^{\circ} \mathrm{C}$.

NTP: Not heat-treated packed; TP: Heat-treated packed; NTUP: Not heat-treated Unpacked; TUP: Heat-treated Unpacked.

It is clear that the infestation rate of Deglet Nour dates increases without significant difference $(p>0.05)$ with storage at room temperature to obtain fully infested dates in the 5 th month $(97.42 \%)$. This same trend with non-significant difference $(p>0.05)$ is observed in unpacked not heat-treated dates stored at $10^{\circ} \mathrm{C}$ but at significantly lower levels $(90.78 \%$ in the 5th month). 
Heat-treated batches continued to be infested during storage, particularly at room temperature (95.74\% in the 5th month), unlike batches stored at $10^{\circ} \mathrm{C}$, which despite the continuation of the infestation but at significantly lower levels. This is more pronounced in the 4 th and 5 th month of storage (69.29\% and $83.32 \%$ respectively). The packaging of dates has shown a remarkable effect in limiting the infestation of date stocks, even not heat-treated, both at room temperature and at $10^{\circ} \mathrm{C}$. Significantly lower levels of infestation $(\mathrm{p}<0.05)$ are therefore observed $(40.65 \%$ and $41.03 \%$ respectively in the 5 th month at room temperature and at $10^{\circ} \mathrm{C}$ ).

The lowest infestation rates were observed in heat-treated-packed batches and monthly storage. These differences were significant compared to all heat-treated batches packed at room temperature. However, the heat-treated-packed-refrigerated batches at $10^{\circ} \mathrm{C}$ differed from those maintained at ambient temperature, by remarkably lower infestation levels ( $p>0.05)$ than all the other batches (26.96\% in the 3rd month).

This content marks a decrease during storage both at room temperature and at $10^{\circ} \mathrm{C}$ and reaches the low contents of $23.34 \%$ and $23.41 \%$ in the 5th month, showing a highly non-significant decrease ( $p>0.05)$. In general, the duration and the temperature of storage exerted a non-significant effect on the decrease in the water content $(p>0.05)$. The heat treatment caused a non-significant decrease $(p>0.05)$ in this water content. This downward trend continues just as much in not heat-treated batches of storage at room temperature as in those stored at $10^{\circ} \mathrm{C}$. The low level of water content observed in the dates analyzed is due to drying out during the shelf life of the dates. Determining the water content presents two main challenges: the first is technological; it informs us about the behavior of dates during the transformation process and the storage period.

The heat treatment-packaging association showed a significant reduction in the water content for all the batches tested both at room temperature or at $10^{\circ} \mathrm{C}$. The heat-treated-packed batches were able to keep average water contents lower than those of the other batches whether they were controls, or heat-treated packed or not but nevertheless lower than those of the not heat-treated batches packed in particular at $10^{\circ} \mathrm{C}$. Packaging in PET film alone remains the best method of preserving against drying out the date by preserving the semi-soft consistency of the Deglet Nour date.

At the reception, the dates had a soluble dry matter content "Brix degree" of $19 \%$. This concentration increased without significant difference $(p>0.05)$ during storage at room temperature to reach concentrations very close to $21 \%$ in the 5 th month of storage.

During storage, the heat-treated-packed batches stored at room temperature showed a non-significant increase in the soluble dry matter content (from 16.95\% in the 1st month to $17.1 \%$ in the 5 th month) with a value close to the control (18\%) obtained in the 2nd month. The heat-treated-unpacked batches stored both at room temperature and at low temperature showed the same trend with significant difference $(p<0.05)$. Similarly, the not heat-treated batches - unpacked and stored at room temperature and at low temperature showed a gradual and significant increase $(p<0.05)$ in the Brix degree which becomes more pronounced from the $3 \mathrm{rd}$ month at room temperature and at from the 2 nd month at 
low temperature and stabilizes during the last months of storage. The comparison of the averages in soluble dry matter content shows that the heat-treated packed batches and stored at room temperature had the value closest to that of the control dates $(19.79 \%)$. The other lots had average soluble dry matter contents higher than that of the control date.

We note that the batches of packed dates heat-treated or not stored at $10^{\circ} \mathrm{C}$ are richer in mineral salts compared to the other batches stored at room temperature $(1.2 \%$ and $1.34 \%$ respectively), with a non- significant decrease $(p>0.05)$ from the 3rd month of storage. All of the batches studied experienced remarkable stability during the storage period at $10^{\circ} \mathrm{C}$ as well as at room temperature. Our results for the eight batches of dates analyzed seem average. It should be noted that in not heat-treated unpacked dates, the ash rate is higher $(1.73 \%)$.

\subsection{Variation of biochemical composition of date fruit}

The Deglet Nour date has total and reducing sugars contents of 70.41 and $20.58 \%$ respectively at room temperature and 67.51 and $25.18 \%$ at $10^{\circ} \mathrm{C}$. During storage, the TUP sample experienced a significant drop $(\mathrm{p}<0.05)$ accentuated for both total sugars and reducing sugars and for the contents of batches of unpacked not heat-treated dates (respectively 46.20 and $19.22 \%$ ) recorded at $10^{\circ} \mathrm{C}$, while at room temperature, these contents are slightly higher (49.10 and 20.63\%). Obviously the temperature and the shelf life have a significant effect on the reduction of the total sugars content of the batch of TUP at $10^{\circ} \mathrm{C}$ and the content of reducing sugars of batch of NTUP dates at room temperature. The effect of heat treatment results in a non-significant decrease in the total sugars content and on the reducing sugars of the other batches of dates studied. In heat-treated dates, the downward trend in total sugars continues although the levels recorded are a little higher compared to not heat-treated batches.

Thus, in the 5th month of storage at room temperature, the total sugars content was maintained at $38.81 \%$, lower than the content recorded in the same month at low temperature for its not heat-treated counterpart. This effect is still noticeable for heat-treated batches and cold storage of $10^{\circ} \mathrm{C}$ where the total sugars contents were maintained at lower levels and close to those of dates stored at room temperature.

The packaging of batches of not heat-treated dates in PET films before their storage made it possible to considerably slow down the decrease in total sugars throughout storage both at room temperature and low and this stabilizing effect was non-significant $(p>0.05)$. The combination of packaging heat treatment has shown decreasing but less abrupt total sugar contents during their storage at room temperature than their respective not heat-treated and unpacked counterparts. However, it is the heat-treated packed batches and stored at $10^{\circ} \mathrm{C}$ which exhibit the best stability of the total sugars contents even up to the 5th month of storage. On reducing sugars, the heat treatment associated with the packaging makes it possible to considerably stabilize the contents of these sugars at levels close to those of fresh Deglet Nour despite the storage both at room temperature and at $10^{\circ} \mathrm{C}$. The sucrose content of batches of unpacked heat-treated dates at $10^{\circ} \mathrm{C}$, shows a significant and gradual decrease $(\mathrm{P}<0.05)$ during storage and reaches a content of $15.32 \%$ in the 5 th month, very low by intake at the initial content of $36.52 \%$, this reduction may be 
justified by the change in the rate of total sugars during the storage period. The heat treatment induced a significant reduction in this content but which remains stable with storage while keeping levels close to their respective not heat-treated controls.

The packaging of the batches packed at room temperature and at $10^{\circ} \mathrm{C}$, showed sucrose contents higher than those of the control batches but lower than those of the heat-treated batches. This effect is more marked in packed heat-treated batches, in particular those stored at $10^{\circ} \mathrm{C}$, where the sucrose contents were recorded moderately close to those of fresh dates.

Mean curves

Storage at $22^{\circ} \mathrm{C} \pm 1{ }^{\circ} \mathrm{C}$
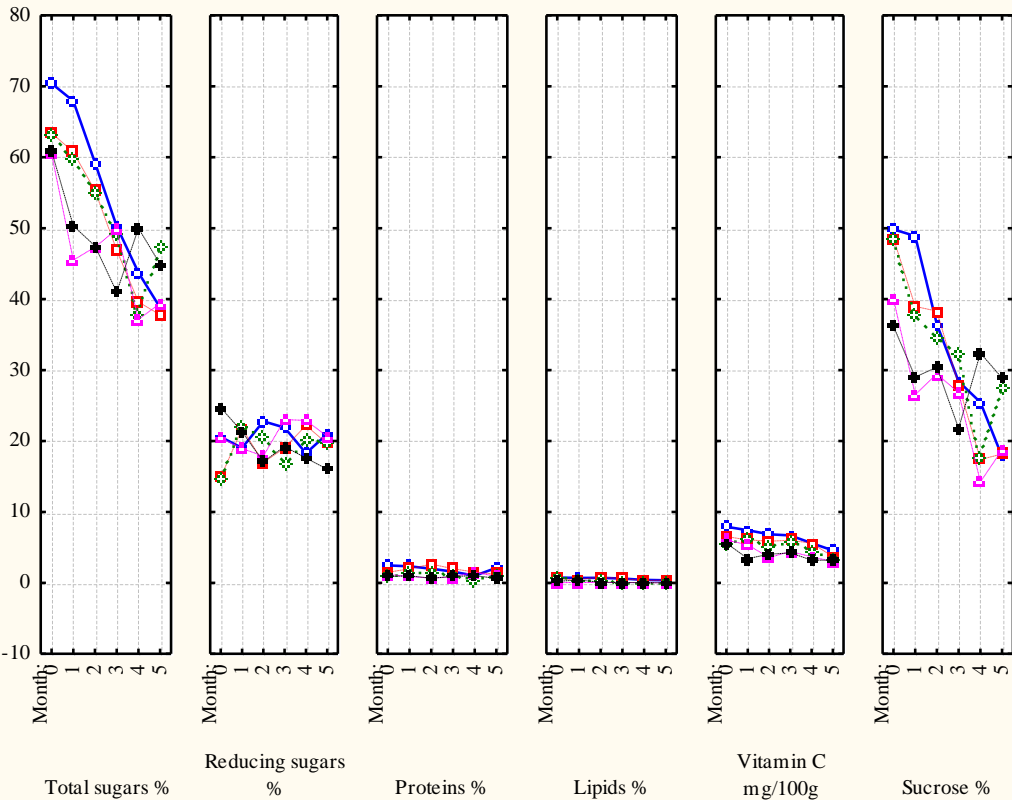

$\rightarrow$ Control

口 NTP

- NTUP

Total sugars $\%$

Reducing sugars

Proteins \%

Lipids \%

- TUP

Mean curves

Storage at $10^{\circ} \mathrm{C} \pm 1{ }^{\circ} \mathrm{C}$
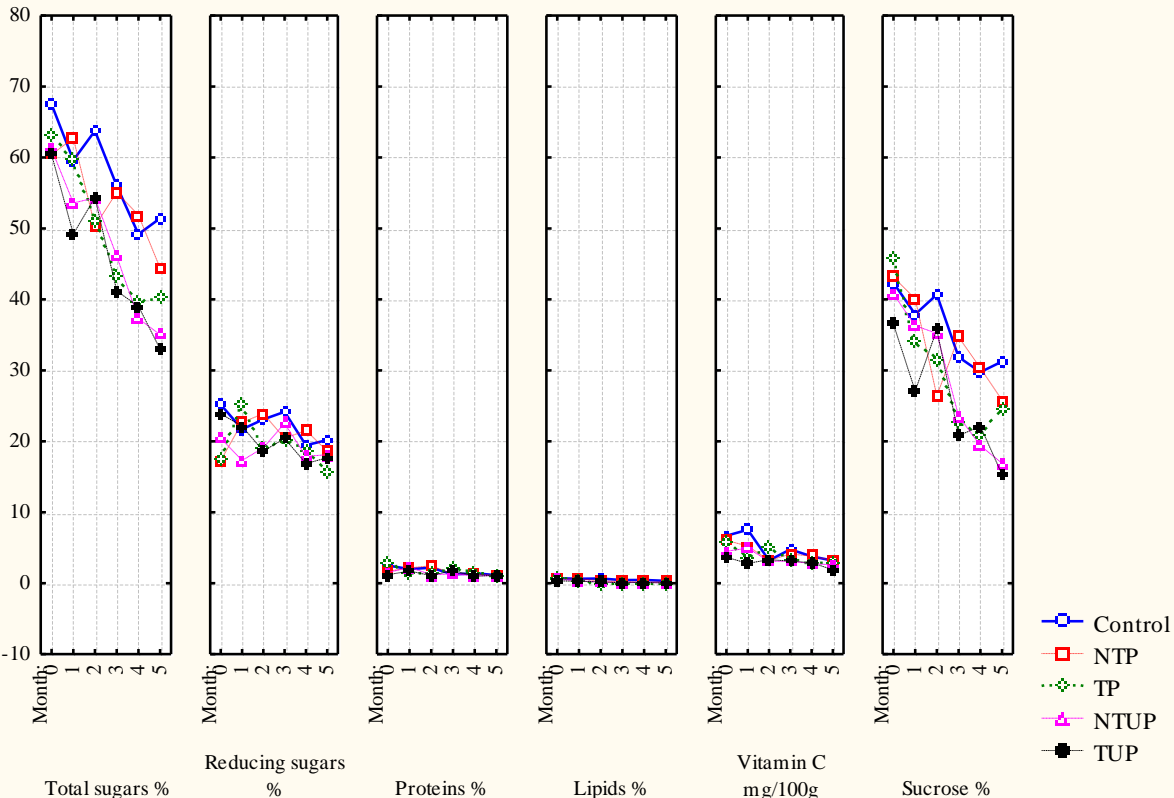

Figure 2. Means values of biochemical composition of the samples of dates, stored at $22^{\circ} \mathrm{C}$ and $10^{\circ} \mathrm{C}$. 
NTP: Not heat-treated packed; TP: Heat-treated packed; NTUP: Not heat-treated Unpacked; TUP: Heat-treated Unpacked.

This may be due to the low water content which constitutes an unfavorable medium for the activity of invertase unlike the soft and semi-soft variety. The values recorded for vitamin $\mathrm{C}$ from the unpacked heat-treated date stored at $10^{\circ} \mathrm{C}$ show a gradual and significant decrease $(p<0.05)$ during storage. The lowest content is obtained in the 5 th month $(1.89 \mathrm{mg} / 100 \mathrm{~g})$ at $10^{\circ} \mathrm{C}$. The heat treatment induced a significant decrease in the vitamin $\mathrm{C}$ content of the heat-treated batches compared to the not heat-treated control date. In these heat-treated batches, the downward trend continues at lower average levels than those of not heat-treated control batches. In the batches unpacked at room temperature, the levels of vitamin $C$ recorded show a decrease with significant values $(p<0.05)$, these contents decrease slightly compared to the other not heat-treated control batches. In batches packed at room temperature and at $10^{\circ} \mathrm{C}$, the levels of vitamin $\mathrm{C}$ recorded show stability during storage with non-significant values ( $>0.05)$, and the levels decrease slightly in the 4th month and in the 5th month compared to the not heat-treated control batches. Heat-treated packed batches at room temperature show higher levels of vitamin $C$ than their counterparts stored at $10^{\circ} \mathrm{C}$.

The protein content of not heat-treated unpacked and heat-treated packed dates stored at room temperature varies significantly $(\mathrm{p}<0.05)$ with respective values in the 5 th month of $0.90 \%$ and 0.63 lower than those of temperature control dates ambient and also at $10^{\circ} \mathrm{C}$, ie $2.11 \%$ and $1.13 \%$ respectively.

It appears that the protein content of unpacked heat-treated dates stored at room temperature is between 0.67 and $1.03 \%$. According to the figures, the amount of protein in this batch is lower has experienced a highly significant decrease $(0.63 \%$ in the 5 th month) compared to the control batch stored at room temperature as well as at $10^{\circ} \mathrm{C}$. We can say that packed batches heat-treated or not heat-treated are more interesting from the point of view of protein content and that the latter are also rich in protein compared to the other batches of unpacked dates. According to our results, batches of unpacked not heat-treated dates stored at room temperature and at $10^{\circ} \mathrm{C}$ are very low in fat with respective values $(0.02-0.06 \%)$ and $(0.04-0.07 \%)$ compared to the control batches with a highly significant decrease at ambient temperature and significant at $10^{\circ} \mathrm{C}$.

Likewise, the batches of unpacked heat-treated dates showed a highly significant decrease from the third month of storage at room temperature as well as at $10^{\circ} \mathrm{C}$. The packaging caused a remarkable reduction from the first month of storage of the batches of heat-treated and packed dates at room temperature and at $10^{\circ} \mathrm{C}$, this reduction was significant. The batches of not heat-treated packed dates stored at room temperature and at $10^{\circ} \mathrm{C}$ are richer in fat compared to the other batches studied. Have experienced a non-significant decrease $(p>0.05)$ throughout the storage period. In all of the batches studied, the not heat-treated packed dates stored at room temperature are relatively richer in fat, the content of which is $0.81 \%$.

\section{Discussion}

The $\mathrm{pH}$ of dates varies according to the stages of development of the date $[9,27]$. Succinic acid, isobutyric acid, citric acid, oxalic acid, and formic acid have been identified in dates [28]. Comparable results have been recorded by Ganbi, 2012 [29], show that date pulp in the fully matured stage (Tamr) has a pH of around 5.65. AL-Gboori and Krepl, 2010 [30], report in the case of four Iraqi varieties (Hallawi, Sayer, Khadrawi and Zahdi), 
$\mathrm{pH}$ values between 5.60-6.70. However, Forouzan et al., 2012 [31], report relatively low $\mathrm{pH}$ values between 3.66 to 5.06 .

The $\mathrm{pH}$ of dates is slightly acidic, this is due to organic acids (citric, malic and oxalic acids) and polyphenol residues in fruits [32]. This positive influence of packaging for modified atmospheres on the chemical characteristics ( $\mathrm{pH}$ and acidity) has also been reported by Gomez and Artes, 2005 [33].These results agree with those of Hofman et al., 2003 [34], for whom low temperature conditioning alone in combination with heat treatment has potential for disinsectization. Reynes, 1997 [35], reported that low temperatures hinder the development of weeds. The packaging constitutes an effective barrier against reinfestation. These results clearly indicate the interest of the combination of refrigeration and heat treatmentin reducing the infestation rate. Our results confirm those of Jang et al., 2001[36], who reported that a heat treatment combined with cold is a very good means of pest control.

The water content of the Deglet Nour date at reception and $24.54 \%$, making it possible to classify our date in the standard of semi-soft varieties [37]. The second concerns the safety of the date, since it is established that the water content has an effect on microbial growth [38]. It has been reported that dates have a very high concentration of sugar which gives them a hygroscopic character leading to a reduction in the availability of water which would lead to a decrease in microbial activity. This property is widely used in the preservation of several foodstuffs [39].

They are lower than those reported by Ganbi, 2012 [29], for a Saudi variety, ie 13.69\%. AL-Gboori and Krepl, 2010 [30], cited lower values compared to those mentioned above, varying between $7.30-9.50 \%$. One of the important qualitative characteristics in determining the flavor of fruits is the total number of the soluble solids shown in the form Brix degree [40]. In the other lots, however, the dates are poorer in ashes. Many authors, including AL-Gboori and Krepl, 2010 [30]; Ganbi, 2012 [29], agree that the date contains ash contents of around $2 \%$. The ash content can vary between less than $1 \%$ to over $6 \%$ [41,42].

The increase in sucrose content observed was also reported by Perez-Tello et al., 2001 [43], during storage at $10^{\circ} \mathrm{C}$ for 2 months, and would be considered by these authors as a physiological response to changes in the cold (chilling injury). The temperature of $10^{\circ} \mathrm{C}$, would be able to reduce the response of the fruit to chilling inury. This same observation was made by Holand et al., 2002 [44]. The low temperatures can prevent the activity of pectin degrading enzymes. Since activity of degrading enzymes such as pectinesterase and also polygalacturonase is one of the most important factors in softening the fruits, any factor that causes delay in the activity of these enzymes can maintain the tissue firmness better [40]. It is well known that dates are important sources of carbohydrates; this was demonstrated in several previous studies on some Arabian date fruits $[45,46]$.

Many authors, including Forouzan et al., 2012 [31]; EL Hadrami and AL-Khayri, 2013 [47], having worked on several varieties of dates affirm that the date sugars would vary according to the variety, pollen, stage of maturation and climate. On the other hand, the soft varieties are very rich in reducing sugars, the semi-soft varieties contain as much sucrose as reducing sugars [6]. Several authors point out that dates contain significant contents in total sugars. Namely: Mimouni, 2009 [48], (67.33 to 71.79\%); AL-Gboori and Krepl, 
2010 [30], (86.10-87.91\%). In general, the results reported by different authors depend in part on the method of analysis used. Nevertheless, all agree that the total sugar content of dates is around 60 to $80 \%$ of the pulp. The proportion of reducing sugars in dates varies depending on the variety studied. Results have been mentioned by Elleuch et al., 2008 [6], according to their study on two Tunisian varieties (Deglet Nour and Allig) of different consistency (semi-soft and soft). They recorded variable values in reducing sugars, namely $27 \%$ and $59 \%$ for the variety Deglet Nour and Allig respectively. However, the reducing sugar content for Algerian varieties Deglet Nour (semi-soft), Degla Beida (dry) and Ghars (soft) fluctuates between 13 and 70\% [48]. The values mentioned by AL-Gboori and Krepl, 2010 [30], are around $73.40-82.70 \%$, which shows that their study material is made up of soft varieties. Dry dates contain a high level of sucrose compared to soft and semi-soft dates Elleuch et al., 2008 [6] (53\%); Mimouni, 2009 [48], (44.82\%).

Date fruits have a low vitamin C content as $100 \mathrm{~g}$ of dates can supply approximately $7 \%$ of the recommended daily intake of this vitamin; nevertheless, the content it is still higher than that of plums, apricots, figs, and raisins $[49,50]$.

The latter although the vitamin C content decreases gradually with storage and nevertheless show a relatively better stability in the last months of storage. Indeed, Seung and Kader, 2000 [51], report that the vitamin C content of fruits and plants is reduced in atmospheres low in $\mathrm{O} 2$. These same authors; report that heat treatment decreases the content of vitamin $\mathrm{C}$, but later limits the loss of this vitamin during cold storage. The lowering of the $\mathrm{O} 2$ content limits the oxidation of ascorbic acid, while the increase of the $\mathrm{CO} 2$ content beyond a threshold specific to each sample, causes its rapid destruction as well as that of the dehydroascorbic acid [15]. According to Reyes et al., 2007 [52], the content of vitamin C can be influenced by various factors, genotypic differences, pre-harvest climatic conditions, cultural practices, maturity and post-harvest procedures including heat treatment. On the other hand, the batches of dates stored at $10^{\circ} \mathrm{C}$ showed stability throughout the storage period with a slight non-significant decrease $(p>0.05)$ in the 5th month of storage. However, AL-Gboori and Krepl, 2010 [30], report values of around 2.78\%. Studies carried out by Alkaabi et al., 2011 [53], on five Saudi varieties, show that dates contain a protein content ranging between 1.16 to $1.62 \%$. Our results are close to those cited above. These results are comparable to those found in the literature which place the protein level between $0.90-2 \%$ [6,54].

On the other hand, these contents are lower than those reported for UAE dates, viz., Gash Gaafar, Gash Habash, Shahla, Bushibal, and Lulu ie 0.2 to 0.5\% [55]. The date contains a small quantity of lipids whose rate varies between 0.43 and $1.9 \%$ of the fresh weight [7]. In conclusion, we can say that packaged batches heat-treated or not heat-treated are more interesting from the point of view of protein content and that the latter are also rich in protein compared to the other batches of unpackaged dates.

The average fat content was $0.14 \mathrm{~g} / 100 \mathrm{~g}$ for fresh dates and $0.38 \mathrm{~g} / 100 \mathrm{~g}$ for dried dates [56]. This was also consistent with other results on date fruit fats [42,47].

\section{Conclusions}


Among the tested simple or combined actions, heat treatment-packaging combination and especially during storage in cold of $10^{\circ} \mathrm{C}$, appeared as the best treatment permitting to maintain the criteria of quality of the date very near of those of the fresh date during the whole 5 months of storage. In particular, we compared the effects of disinfestation by heat treatment or by using a combined heat treatment-MAP packaging treatment. The main objective of the study that we conducted was indeed to show the feasibility and the advantages of this technological alternative. Indeed, this study has highlighted the advantages and disadvantages of the introduction of the MAP technique in the packaging of dates which improves its marketing. During the study, we found that the packaging seems to have a positive effect on acidity, especially in batches stored at $10^{\circ} \mathrm{C}$. This combination seems to have a better effect on preserving the acidity of the date, thus allowing the pleasant flavor of Deglet Nour to be preserved. The packaging of dates has shown a remarkable effect in limiting the infestation of date stocks, even not heat-treated, both at room temperature and at $10^{\circ} \mathrm{C}$.

The heat treatment-packaging association showed a significant reduction in the water content for all the batches tested both at room temperature and at $10^{\circ} \mathrm{C}$. Packaging in PET film alone remains the best method of preserving against drying out the date by preserving the semi-soft consistency of the Deglet Nour date. The packaging of batches of not heat-treated dates in PET films before their storage made it possible to considerably slow down the decrease in total sugars throughout storage both at room temperature and low and this stabilizing effect was not significant ( $p>0.05)$. On the reducing sugars, the heat treatment associated with the packaging makes it possible to considerably stabilize the contents of these sugars at levels close to those of fresh dates despite the storage, whether at room temperature or at $10^{\circ} \mathrm{C}$. The heat treatment induced a significant decrease in the vitamin $\mathrm{C}$ content of the heat-treated batches compared to the not heat-treated control date. In these heat-treated batches, the downward trend continues at lower average levels than those of not heat-treated control batches. The heat-treated or not heat-treated packed batches are more advantageous from the point of view of protein content and that the latter are also rich in proteins compared to the other batches of unpacked dates. The packaging caused a remarkable reduction in lipids from the first month of storage of the batches of heat-treated and packed dates at room temperature and at $10^{\circ} \mathrm{C}$. The heat treatment-packaging-storage at $10^{\circ} \mathrm{C}$ combination represents a way of conservation permitting to assure an optimal commercial quality of the dates. The dates thus treated present an excellent faculty to storage beyond the 05 tested months. In terms of prospects for this work, the relationships between date polyphenols and polyphenoloxidase and peroxidase activities deserve special study.

Funding: This research received no external funding.

Institutional Review Board Statement: Not applicable.

Informed Consent Statement: Not applicable.

Data Availability Statement: Not applicable.

Conflicts of Interest: The authors declare no conflicts of interest. 


\section{References}

1. Marzena, J.; Kuras, M.; Zielin'ska-P.; Justyna, D.; Joanna, J. Determination of the elemental composition and antioxidant properties of dates (Phoenix dactyliferia L.) originated from different regions. J Food Sci Technol. $2020,1$. https://doi.org/10.1007/s13197-020-04314-8.

2. FAOSTAT. Crops. https://www.fao.org/faostat/en/\#data/QC. 2019, Accessed 21 May 2019.

3. Al-Yahyai, R.; Manickavasagan.; A. An overview of date palm production. In: Manickavasagan A, Essa MM, Sukumar E (eds) Dates: production, processing, food, and medicinal values, CRC Press, Boca Raton. 2012, 3-12. https://doi: 10.1002/9781118292419.ch1

4. Baliga, MS.; Baliga, BBV.; Kandathil, SM.; Bhat, HP.; Vavalil, PK. A review of the chemistry and pharmacology of the date fruits (Phoenix dactylifera L.). Food Res Int. 2011, 44, 1812-1822. https://doi.org/10.1016/j.foodres.2010.07.004.

5. Ahmed, IA.; Ahmed, AWK.; Robinson, RK. Chemical composition of date varieties as influenced by the stage of ripening. Food Chem. 1995, 54, 305-09. https://doi: 10.1016/0308-8146(95)00051-j.

6. Elleuch, M.; Besbes, S.; Roiseux, O.; Blecker, C.; Deroanne, C.; Drira, N.; Attia, H. Date flesh: Chemical composition and characteristics of the dietary fiber. Food Chem. 2008, 111, 676-82. https://doi: 10.1016/j.foodchem.2008.04.036.

7. Biglari, F. A.; Alkarkhi, F. M.; and EASA, A.M. Cluster analysis of antioxidant compounds in dates (Phoenix dactylifera L.): Effect of long-term cold storage. Food. Chemistry. 2009, 112, 998-1001. https://doi: 10.1016/j.foodchem.2008.06.063.

8. Al-Turki, S.; Shahba, MA.; Stushnoff, C. Diversity of antioxidant properties and phenolic content of date palm (Phoenix dactylifera L.) fruits as affected by cultivar and location. J Food Agric Env. 2010, 8, 253-60. https://doi.org/10.1234/4.2010.1495.

9. Kulkani, S.G.; Vijayanand, P.; Aksha, M.; Reena, P.; and Ramana, K.V.R. Effect of dehydration on the quality and storage stability of immature dates (Phoenix dactylifera L.). L.W.T. 2008, 41, 278-283. https://doi: 10.1016/j.lwt.2007.02.023.

10. Mansouri, A.; Embarek, G.; Kokkalou, E.; Kefalas, P. Phenolic profile and antioxidant activity of the Algerian ripe date palm fruit (Phoenix dactylifera L.). Food Chem. 2005, 89, 411-20. https://doi.org/10.1016/j.foodchem.2004.02.051.

11. Vanita, B.; Punia, D. Nutritional composition of fruit of four date palm (Phoenix dactylifera L.) cultivars grown in Haryana, India. Asian J Dairy Food Res. 2016, 35(4), 331-334. https ://doi.org/10.18805/ajdfr .v35i4 .6635.

12. CEE-ONU-DDP-08. Standard for the commercialization and commercial quality control of dates. In "Norme CEE-ONU-DDP-08" (N. UNIES, ed.), New York and Geneva. https://www.unece.org/fileadmin/DAM/trade/agr/standard/dry/Standards/DDP08_Dates_2010_f.pdf.

13. Yahia, E.M. Date. In: Gross KC, Wang CY, Saltveit M, editors. The Commercial Storage of Fruits Vegetables and Florist and Nursery Stocks. Agriculture Handbook \# 66. Beltsville, Maryland, USDA. 2004, 672.

14. Navarro, S. Postharvest treatment of dates. Stewart Postharvest. 2006, Rev 2: 1-10. https://doi: 10.2212/spr.2006.2.1.

15. Khali, M. Effects of simple and combined treatments on the biology and biochemistry of the date being conserved; Ph.D. thesis in Food Science and Nutrition, Higher National Agronomic School, El Harrach, Algiers, Algeria. 2008 , 5. http://dspace.ensa.dz:8080/xmlui/handle/123456789/770.

16. Parinaz, A.; Omid, M.; Behjat, T. The effect of nanocomposite packaging carbon nanotube base on organoleptic and fungal growth of Mazafati brand dates Department of Food Science and Technology, College of Agriculture, Shahr-e- Qods Branch, Islamic Azad University, Tehran, Iran Int Nano Lett. 2014, 1-2.https://doi: 10.1007/s40089-014-0098-3.

17. A.O.A.C. Official Methods of Analysis, 19th ed. Association of Official Agri. Chemists, Inc, Washington D.C., USA. 2012. https://www.aoac.org/.

18. AL-Qurashi, A.D.; Awad, M.A. Quality characteristics of bisir 'Barhee' dates during cold storage as affected by postharvest dipping in gibberellic acid, naphthaleneacetic acid and benzyladenine. International Journal of Tropical and Subtropical Horticulture. 2011, 66, 343-352. https://doi: 10.1051/fruits/2011048.

19. Doukani, K.; and Tabak, S. Article Physicochemical profile of the fruit "Lendj" (Arbutus unedo L.) Laboratory of Agro-Biotechnology and Nutrition in Semi Arid Zones. Journal Nature E Technology. 2014. https://www.asjp.cerist.dz/en/article/39941.

20. A.O.A.C. Official methods of analysis. Association of Official Analytical Chemists, 15th edition, Washington, D.C., USA. 1990.

21. Laurey, S. Protein structure core facility, Omaha, NE. 1997, 68, 198-4525.

22. Folch, J. M. Lees, G.H.S. Stanley, A simple method for the isolation and purification of total lipids from animal tissues, J. Biol.Chem. 1957, 226, 497-509.

23. A.O.A.C. Official Method of Analysis (17th ed.). Gaithersburg: Association of Official Analytical Chemists. 2000. https://www.aoac.org/.

24. Audigie, C.L. Biochemical analysis manipulation, Edition Doin, Paris. 1978, 27-74.

25. Langemeier, J.M. Rapid method for sugar analysis of doughs and baked products. Cereal Chem. 1995, 72 349-351. https://www.aaccnet.org/publications/cc/backissues/1995/Documents/72_349.pdf.

26. Dhouibi, M.H.; and Jarraya, A. Date Worm, carob moth : Ectomyelois ceratoniae. Document Inrat et GID. 1996, 9.

27. Iqbal, M.; Munir, I.M.; and Niamatullah, M. Physico-Chemical characteristics of date palm (Phoenix dactylifera L.) cultivars at various maturity stages under environmental conditions of Dera Ismail Khan. J. Agric. Res. 2011, 49 (2), $249-261$. https://apply.jar.punjab.gov.pk/upload/1374664516_90_36_1651--JAR-4000-1_\%2811\%29.pdf. 
28. Hamad, I.; AbdElgawad, H.; Al Jaouni, S.; Zinta, G.; Asard, H.; Hassan, S.; Hegab, M.; Hagagy, N.; Selim, S. Metabolic analysis of various date palm fruit (Phoenix dactylifera L.) cultivars from Saudi Arabia to assess their nutritional quality. Molecules. 2015, 20, 13620-13641. https://doi: 10.3390/molecules200813620.

29. Ganbi, H. Production of Nutritious High Quality Date (Phoenix dactylifera L.) Fruits Syrup (Dibs) by using some Novel Technological Approaches. Journal of Applied Sciences Research. 2012, 8(3), 1524-1538. http://www.aensiweb.com/old/jasr/jasr/2012/1524-1538.pdf.

30. Al-Gboori, B.; and Krepl, V. Importance of date palms as a source of nutrition. Journal Agricultura Tropicaet Subtropica. 2010, 43 (4), 341-347. https://www.agriculturaits.czu.cz/pdf_files/vol_43_4_pdf/badir.pdf.

31. Forouzan, S.; Rahimirad, A.; and Banafshechin, E. Survey of Iranian Date Palm Concentrate Chemical Characteristics. Middle-East Journal of Scientific Research. 2012, 12 (7), 1009-1011. https://doi: 10.5829/idosi.mejsr.2012.12.7.66194.

32. Al Shahib, W.; Marshall, R.J. The fruit of the date palm: it's possible use as the best food for the future. Int. J. Food. Sci. Nutr. 2003, 54(4), 247-259. https://doi: 10.1080/09637480120091982.

33. Gomez, P.A, and Artés, F. Improved keeping quality of minimally fresh processed celery sticks by modified atmosphere packaging. LWT. 2005, 38, 323-329. https://doi: 10.1016/j.lwt.2004.06.014.

34. Hofman, P.J.; Stubbings, B.A.; Adkins, M.A.; Corcoran,R.J.; White, A.; and Woolf, A.B. Low temperature conditioning before cold disinfestation improves Hass avocado fruit quality. Postharvest Biol. Techn. 2003, 28, $123-133$. https://doi: 10.1016/S0925-5214(02)00175-8.

35. Reynes, M. Influence of a microwave disinfestation technique on the physico-chemical and biochemical quality criteria of the date. Doctoral thesis of the National Polytechnic Institute of Lorraine. 1997, 182. http://www.sudoc.fr/182991970.

36. Jang, E.B, Chan H.T, Nishijima K.A, Nagata J.T, Mc Kenny M.P, Carvalho L.A, and Schneider E.L. Effect of heat shock and quarantine cold treatment with a warm temperature spike on survival of Mediterranean fruit fly eggs quality in Hawaii grown Sharwil avocado. Postharvest Biol And Techn. 2001, 21, 311-320. https://doi.org/10.1016/S0925-5214(00)00174-5.

37. Albano, P.O. Knowledge of palm trees. Crops and uses. Edition SUD. 2002, 145. ISBN 10: 2744903035. ISBN 13: 9782744903038.

38. Beuchat, L.R, and Scouten A.J. Combined effects of water activity. Temperature and chemical treatments on the survival of Salmonella and Escherichia coli O157: H7 on alfalfa seeds. J. Appl. Microbiol. 2002, 92, 382395. https://doi.org/10.1046/j.1365-2672.2002.01532.x.

39. Kang, J.; Tang, S.; Liu, R.H.; Wiedmann, M.; Boor, K.J.; Bergholz, T.M.; and Wang, S.J. Effect of curing method and freeze thawing on subsequent growth of Listeria monocytogenes on cold smoked salmon. J. Food. Prot. 2012, 75(9), $1619-1626$. https://doi: 10.4315/0362-028X.JFP-11-561.

40. Wills, R.; Golding, J. Postharvest: an introduction to the physiology and handling of fruit and vegetables. UNSW press, Australia. 2016. https://trove.nla.gov.au/work/11501498

41. Assirey, E.A.R. Nutritional composition of fruit of 10 date palm (Phoenix dactylifera L.) cultivars grown in Saudi Arabia. J Taibah Univ Sci. 2014, 9,75-79. https ://doi.org/10.1016/j.jtusc i.2014.07.002.

42. Abdul-Hamid, NA.; Mustaffer, NH.; Maulidiani, M.; Mediani, A.; Ismail, IS.; Tham, C.L.; Khalid, S.K.; Abas, F. Quality evaluation of the physical properties, phytochemicals, biological activities and proximate analysis of nine Saudi date palm fruit varieties. J Saudi Soc Agric Sci. 2018. https ://doi.org/10.1016/j.jssas.2018.08.004.

43. Perez-Tello, G.O.; Silva-Espinoza, B.A.; and Vargas-Arispuro, T. Effect of temperature on enzymatic and physiological factors related to chilling injury in Carambola fruit (Averrhoa carambola L.). Biochem. and Biophysic. Research Communications. 2001, 287, pp: 846-851. https://doi: 10.1006/bbrc.2001.5670.

44. Holand, N.; Menezes, H.C.; and Lafuente, M.T. Carbohydrates as related to the heat induced chilling tolerance and respiratory rate of fortune mandarin fruit harvested at different maturity stages. Postharvest Biol. And techn. 2002, 25, 181-191. https://doi.org/10.1016/S0925-5214(01)00182-X.

45. Bouhlali, E.T.; Ramchoun, M.; Alem, C.; Ghafoor, K.; Ennassir, J.; Zegzouti, Y.F. Functional composition and antioxidant activities of eight Moroccan date fruit varieties (Phoenix dactylifera L.). J Saudi Soc Agric Sci. 2017, 16, $257-264$. https://doi.org/10.1016/j.jssas.2015.08.005.

46. Alghamdi, A.A.; Awadelkarem, AM.; Sharif Hossain, A.B.M.; Ibrahim, N.A.; Fawzi, M.; Ashraf, S.A. Nutritional assessment of different date fruits (Phoenix dactylifera L.) varieties cultivated in Hail province, Saudi Arabia. Biosci Biotech Res Comm. 2018, 11(2), 263-269.

47. El Hadrami, A.; and Al-Khayri, J.M. Socioeconomic and traditional importance of date palm. Emir. J. Food. Agric. 2013, 25 (4), 371-385. https://www.ejfa.me/index.php/journal/article/view/1378.

48. Mimouni, Y. Development of a technique for extracting date syrups; comparison with high fructose syrups (HFCS) from the starch industry. Magister Thesis. 2009, 66-67. https://bu.univ-ouargla.dz/Mimouni_Yamin.pdf?idthese=99.

49. Ahmed, J.; Al-Jasass, F.M.; Siddiq, M. Date fruit composition and nutrition. In: Siddiq M, Aleid SM, Kader AA (eds) Dates: postharvest science, processing technology and health benefits, 1st edn. Wiley, Chichester. 2014, 261-283

50. Nasir, M.U.; Hussain, S.; Jabbar, S.; Rahid, F.; Khalid, N.; Mehmood A.A review on the nutritional content, functional properties and medicinal potential of dates. Sci Lett. 2015, 3(1), 17-22.

51. Seung, K.; Lee, and Kader, A.A. Preharvest and postharvest factors influencing vitamin C content of horticutural crops. Postharest Biol.and Techn. 2000, 20, 207-220. https://doi.org/10.1016/S0925-5214(00)00133-2.

52. Reyes, L.F.; Villarreal, J.E.; and Zevallos, L.C. The increase in antioxydant capacity after wounding depends on the type of fruit or vegetable tissue. Food Chem. 2007, 101, 1254-1262. https://doi.org/10.1016/j.foodchem.2006.03.032. 
53. Alkaabi, J.M.; Al Dabbaghl, B.; Ahmad, S.; Saadi, H.F.; Gariballa. S.; and Al Ghazali, M. Glycemic indices of five varieties of dates in healthy and diabetic subjects. J. Nutr. 2011, 59, 1-10. https://doi: 10.1186/1475-2891-10-59.

54. Al Hooti, S.; Sidhu. J.S.; and Qabarzad, H. Chemical composition of seeds date fruit cultivars of United Arab Emirates. Journal of Food Science and Technology. 1997, 35, 44-46.

55. Al-Farsi, M.; Lee, C.Y. Nutritional and functional properties of dates: a review. Crit Rev Food Sci Nutr. 2008, 48(10), 877-887. https ://doi.org/10.1080/10408 390701724264. 